\title{
Modelling Employee Commitment in the Nigerian Manufacturing Sector
}

\author{
Helen Enerunmone Ogheneyoma LUCENT-IWHIWHU (Mrs.) MBA, M.Sc \\ Department of Business Administration and Management \\ Delta State Polytechnic, Ozoro, Delta State, Nigeria
}

\begin{abstract}
The study modeled employee commitment in the Nigerian manufacturing sector using Guinness Nigeria Plc as case study. The study ascertained the impact of reward systems, supervisor-subordinate relationship and opportunities for career development on employee commitment in the Nigerian manufacturing sector. The population of the study consists of all employees of Guinness Nigeria Plc, Benin City. A sample of one hundred (100) employees was randomly taken. A structured questionnaire was used to elicit data from respondents for the study. Out of the 100, eighty eight (88) were validly filled and returned. Both descriptive and inferential statistics were used for data analyses. The findings revealed that reward system, supervisor-subordinate relationship and opportunity for career development positively and significantly impact employee commitment in Guinness Nigeria Plc. The study recommends that Guinness Nigeria Plc should sustain and improve on current strategy on reward system to enhance commitment among employees in the workplace. Also, cordial relationship between employees (subordinate) and supervisor should be sustained in the operations of organisations to promote trust and commitment in the workplace.
\end{abstract}

Keywords: Career development, employee commitment, manufacturing, reward system, workplace.

DOI: $10.7176 / \mathrm{EJBM} / 11-15-16$

Publication date:May $31^{\text {st }} 2019$

\section{$1 \quad$ Introduction}

Employee commitment serves as a critical component of human resource. This is because it is a multifaceted and multidimensional concept that comprises affective, continuance and normative commitment (Meyer, Allen \& Allen, 1997). Abuga (2010) and Greenberg and Baron (1997) described employee commitment as the extent to which the individual identifies and is involved with his or her organization and/or unwilling to leave it. The concept of employee commitment has generated a lot of interests among researchers in the field of organizational behaviour and organizational psychology (Albdour \& Altarawneh, 2014). This probably emanates from its important role in ensuring organizational survival and competiveness.

Employee commitment describes a strong desire by the employee to remain a member of the organization; a strong belief in, and acceptance of, the values and goals of the organization; and a readiness to exert considerable effort on behalf of the organization (Mowday, Porter \& Steers, 1982). It is the psychological or emotional attachment to, identification with, and involvement in an organization (Arnold, 2005). This psychological bond could be occasioned by the satisfaction that employee derived in carrying out their responsibilities in the organisation. Employee commitment is an important ingredient in enhancing organizational survival, work productivity, and firm's profitability. This is however dependent on the relative stability of the business environment that the organization is operating in.

It is an indisputable fact that the commitment of the majority of workers in Nigeria to work has been notably battered in recent years due to different factors. Among these factors include the rising costs of living and particularly the prevalent downsizing and rightsizing in most companies occasioned by the unfavourable business climate (Njoku, Ugwulebo \& Iheriohanma, 2018). Thus, there is every tendency that retained employees after a layoff exercise will lower their commitment to work in the organization.

Study by Hanaysha and Tahir (2015) highlighted the importance of employee satisfaction on fundamental aspects of employee's behaviour at the workplace. Employee commitment is a critical and desirable behaviour required for the effective and efficient attainment of organizational goals and objectives. Jahangir, Akbar and Haq (2004) have shown that employees that derive satisfaction from their jobs are more inclined to remain committed to their present organization for a longer time; and thus exhibit high levels of affective and normative commitment. It is against this backdrop that, this study empirically investigates the determinants of employee commitment in the Nigerian workplace especially the manufacturing sector because the sector plays a very critical role in Nigeria's economy. Nigerian manufacturing sector is not only a major source of employment but it also acts as an important stream of revenue. 
The main objective of this study therefore is to model the determinants of employee commitment in the Nigerian manufacturing sector. The specific objectives are; to:

i. ascertain the impact of reward systems on employee commitment in the Nigerian manufacturing sector;

ii. determine the impact of supervisor-subordinate relationship on employee commitment in the Nigerian manufacturing sector; and

iii. ascertain the relationship between opportunities for career development on employee commitment in the Nigerian manufacturing sector.

\section{$2 \quad$ Literature Review}

\subsection{Concept of Employee Commitment}

Different scholars have defined employee commitment in different ways. According to Bateman and Strasser (1984:95), "employee commitment is a multidimensional in nature, involving an employee's loyalty to the organization, willingness to exert effort on behalf of the organization, degree of goal and value congruency with the organization, and desire to maintain membership". Miller and Lee (2001) explain employee commitment as the emotional attachment between the individual and his or her organization. Employee commitment describes employee's strong belief in what the organization stands for. Cohen (2003) defined employee commitment as the extent to which organizational employees are desirous to continue and identify organizational goals and values. Meyer, Becker and Van dick (2006) defined employee commitment as the psychological psychosomatic or inner bond that exists between an employee and his or her organization. It is the emotional attachment and a sense of belonging employees feel towards their employers and organizations that propel them to want to imbibe and identify with what the organization stands for (Nartech, 2012). Abdurrahim (2012) asserted that organizations need commitment from their employees in order to reduce costs and improve performance, as well as improved service and product quality for the achievements of desired organizational goals and objectives.

\subsection{Dimensions of Employee Commitment}

Employee commitment can be broadly categorized into three namely: affective, continuance and normative commitment (Allen \& Meyer, 1990; Jason et al., 2011). Affective commitment is an employee's psychological or emotional attachment and identification with an organization. It is the tendency that an employee will remain with an organisation based on emotional attachment (Jason et al., 2011). It is difficult to entice such employee to leave the organization because he or she is psychological attached to the organization. In other words, employees in this category will stay with their organization because they love to. In the real sense, affective commitment makes an employee hold positive affection toward his or her organization and translates in his or her wish to see the organization succeed in achieving its predetermined goals and objectives. Akpan (2013) asserts that affective commitment is more concerned with intrinsic factors than extrinsic factors. Therefore, maintaining good employee relation, involvement of employees in policy and decision-making will help to enhance affective commitment among employees of manufacturing firms. An employee with affective commitment always feels proud of their membership to their organization and exhibit higher level of continuance and normative commitment (Gangai \& Agrawal, 2015).

Continuance commitment has to do with the degree to which employee perceive the associated cost of leaving the organization to another as enormous. Employees in this category are not willing to lose membership of their organization because of the economic and social importance attached such as loosing relationship with old time friends and colleague; forfeiting accrued salaries, pension benefits and promotion (Jason et al., 2011). An employee with continuance commitment finds it difficult to give up or exit his or her organization due to the fear of the unknown and having few or lack of available alternative in sight (Gangai \& Agrawal, 2015).

Normative commitment is the employees' sense of loyalty or obligation to remain with their organization irrespective of the circumstance whether good or bad. Employee in this category might find it difficult to leave their organization even if they are not longer comfortable with job role. This occurs mostly when the organization has invested in an employee through quality training while such employee are equally willing to reciprocate by staying or remain with their organization overtime (Azeez, Jayeoba \& Adeoye, 2016). For instance, when an employee is sent by his or her employer for conferences and seminar to improve his or her skills for the discharge of job task, he or she sometimes have a sense of duty to stay or remain a member of an organization as means of giving back to the system on returning from such training. In that case, employee stays because they ought to (Azeez et al., 2016). 


\subsection{Determinants of Employee Commitment}

In the context of this study, three factors that can determine employee commitment in the workplace are discussed. These include reward system, supervisor-subordinate relationship and opportunities for career development.

\subsubsection{Reward System}

Eric (1994) defined rewards to include all types of benefits, from cash payments to working conditions. Reward is the remuneration that an employee receives in return for the work and services he/she had performed in the organisation (Goodale, Koerner \& Roney, 1997). Employee reward system in this context is examined from the perspective of pay. Pay, according to Luthans (1992) does not only serve to meet physiological ends but also attaining higher level of needs. Prior study of Voydanoff (1980) indicates that pay is a major factor in explaining employees' job satisfaction and commitment. According to William et al. (2006:21) "actual pay level and pay satisfaction is probably a function of the discrepancy of perceive pay level and the amount that employee believes their pay should be." The higher the perception of gap or discrepancy between pay and task performed, the higher the job satisfaction or dissatisfaction among employees. Meanwhile, Lawler (1991) had presented a perspective that views pay satisfaction as a discrepancy between how much pay one feels one should receive and how much one feels is actually received.

\subsubsection{Supervisor-Subordinate Relationship}

Cordial relationship between subordinate (employee) and supervisor is critical in sustaining employee commitment in the workplace. According to Sitkin and Roth (1993), it is considered that supervisors' higher status, immense power, increased information and opportunities to wield control which creates a situation where the employees are facing greater threats, ambiguity and dependence for the reason that they often are subjected to their supervisors as regards promotions, pay raises or in terms of job security, then such relationships characterized by asymmetries open up the subordinate employee to likely vulnerability and exploitation. Therefore, for the supervisor and subordinate to work in cooperation and harmony and for the subordinate to demonstrate loyalty, trust becomes a very salient issue in the supervisor-subordinate relationship.

Mayer et al. (1995) posit that ability, benevolence and integrity are three fundamental factors of trustworthiness in nurturing trust in supervisor-subordinate relationship. Ability is about whether the supervisor has the skills and resources to fulfill the employee's expectations. In organisational context, goodwill and sincerity might not be enough for the supervisor to be effective. That is why it is important for the supervisor to have experience, knowledge, skills, power and resources to meet the employee's needs (Singh \& Srivastana, 2009). Benevolence, on the other hand is about the supervisor's genuine care for subordinates and genuine concern in his/her association with them (Burke et al., 2007). A benevolent supervisor makes employees to have the feeling that their ideals and well-being will be protected by the supervisor while integrity, the third factor significant in trust building, holds in terms of the employee's expectation that supervisors keep to some distinct values which are considered to be principled and worthy of being embraced by the employees (Lapierre, 2007). Employees do scrutinize their supervisor's activities, behaviours, image in and out of the organisation, and consistency between their behaviours. Mayer et al. (1995) asserted that employees feel that the supervisor know-how to moral values and standards promote trust in them. High level of commitment by employees to organizational goals and objectives is a function of trust which is built on ability, benevolence and integrity.

\subsubsection{Opportunities for Career Development}

According to Malaolu and Ogbuabor (2013), organizations have been embarking on training and capacity building for their employees so as to enhance their productivity. Up-to-date training of employee forms critical part of their career development. Training refers to intentional intervention to help the individual (or the organisation) to become competent, or more competent, at work. Kitson (2003) defines training as a learning activity that is intended for instant effect, for the job or role that an individual is currently doing. Similarly, the objective of training is seen as creating, in the employee, both the inspiration and the abilities in such a way that the organisation has complete assurance that the employee will react and perform in exactly the form required (Hall, 1990).

Opportunities for career development refer to the availability of a learning environment in the workplace where development activities result in the attainment of cognitive, affective and skill-based learning outcomes (Noe, Wilk, Mullen \& Wanek, 2014). It also indicates the degree to which organisational members feel their workplace as needing the utilisation of prevailing knowledge and skills, as well presenting them opportunities to acquire novel skills and practices (Morrison, Cordery, Girardi \& Payne, 2005). Truelove (1992) asserts that development occurs where organisational members learn through practice to be more knowledgeable not only in their existing jobs, but also in upcoming posts. Kitson (2003) also defines development as a learning activity that is planned for 
future effect, for a role or job to be done in the future by an employee. Opportunities for career development can engender commitment of employee towards organizational goals and objectives.

\section{$3 \quad$ Methodology}

3.1 Research design: The research design adopted for this study is survey. The adoption of survey research design is due to its high flexibility of data collection, potential to build a rapport and a high degree of diversity of questions to capture various perceptions of respondents (Malhotra, Birks \& Wills, 2013).

3.2 Population and sample: The population of the study consists of all employees of Guinness Nigeria Plc, Benin City. A sample of one hundred (100) employees was randomly taken. Questionnaires were distributed to the sampled employees across different cadre. Out of the 100, eighty eight (88) were validly filled and returned.

3.3 Instrumentation: Structured questionnaire was used to collect data. The questionnaire was divided into two sections. Section A contained demographic characteristics (gender, age, educational qualification and cadre) of the employees. Section B contained questions on employee commitment and its determining factors such as reward system, supervisor-subordinate relationship and opportunity for career development (See Appendix A for details). The research instrument was validated by human resource experts. Cronbach's Alpha was used to check for the internal consistency of the items in each of the variables under investigations. The Cronbach's alpha values for affective commitment, continuance commitment, normative commitment, reward system, supervisorsubordinate relationship and opportunity for career development are $0.732,0.821,0.674,0.753,0.829$ and 0.763 respectively.

3.4 Model Specification: The determining factors of employee commitment examined in this study are reward system, supervisor-subordinate relationship and opportunity for career development along the different dimensions of employee commitment. The models for this study are mathematically expressed as follows:

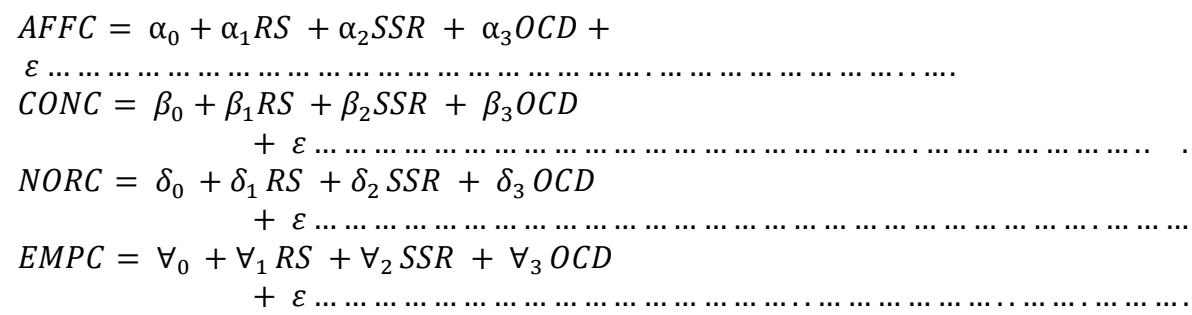

Where: $\mathrm{EMPC}=$ Employee commitment; AFFC = Affective commitment; CONC = Continuance commitment; NORC $=$ Normative commitment; RS = Reward system; SSR = supervisor-subordinate relationship; and OCD = Opportunity for career development

$\alpha_{0}, \beta_{0}, \delta_{0}$ and $\forall_{0}$ are constant. $\varepsilon=$ Error term. A priori expectations: $\alpha_{1} \ldots \alpha_{3} ; \beta_{1} \ldots \beta_{3} ; \delta_{1} \ldots \delta_{3} ; \forall_{1} \ldots \forall_{3}>$ 0

3.5 Estimation technique: The research data were analysed using descriptive and inferential statistics. Descriptive statistics used include frequency distribution, mean and standard deviation. Ordinary least square regression analysis was used to model the relationship between each of the dimensions of employee commitment and its determinants. All analyses were conducted using Statistical Package for Social Sciences (SPSS 24.0 Version) at $5 \%$ level of significance.

\section{$4 \quad$ Results and Discussions}

\subsection{Description of Respondents' Demographic Attributes}

The demographic attributes of interest in this study are respondents' gender, age, educational qualification, and cadre. Table 1 below shows the presentation and analyses of data relating to these demographic characteristics. 
Table 1: Respondents' demographic attributes

\begin{tabular}{|c|c|c|c|c|}
\hline $\mathbf{S} / \mathbf{N}$ & Variable & Category & Frequency & Percent \\
\hline \multirow{3}{*}{1} & \multirow{3}{*}{ Gender } & Male & 65 & 73.9 \\
\hline & & Female & 23 & 26.1 \\
\hline & & Total & 88 & 100 \\
\hline \multirow{5}{*}{3} & \multirow{5}{*}{ Age } & Below 20years & 2 & 2.3 \\
\hline & & 20-30years & 7 & 8.0 \\
\hline & & 31-40years & 50 & 56.8 \\
\hline & & 41 and above & 29 & 33.0 \\
\hline & & Total & 88 & 100 \\
\hline \multirow{5}{*}{4} & \multirow{5}{*}{ Educational qualification } & Secondary & 2 & 2.3 \\
\hline & & Diploma/NCE & 10 & 11.4 \\
\hline & & First Degree & 56 & 63.6 \\
\hline & & Postgraduate & 20 & 22.7 \\
\hline & & Total & 88 & 100 \\
\hline \multirow{3}{*}{5} & \multirow{3}{*}{ Cadre } & Senior & 82 & 93.2 \\
\hline & & Junior & 6 & 6.8 \\
\hline & & Total & 88 & 100 \\
\hline
\end{tabular}

Table 1 shows that majority of the respondents sampled are male, which are 65 accounting for $73.9 \%$ of the respondents. The female respondents consist of 23 that represent $26.1 \%$. The age distribution shows that majority of the respondents $(50,56.8 \%)$ of the respondents were between $31-40 y e a r s$ old. This is followed by employees that are 41 years old and above. This group accounts for $33 \%$ of the total respondents. Finally, age groups $30 y e a r s$ and below account for only $10.3 \%$ of the total respondents. Only $2.3 \%$ of the respondents had secondary education as their highest educational qualification. $10(11.4 \%)$ of the respondents have Diploma/NCE while $56(63.6 \%)$ of the respondents have first degree (HND/B.Sc/B.Eng Degree). Twenty (20) respondents have postgraduate qualifications. This accounts for $22.7 \%$. Out of the total respondents, 82 of them are in senior staff cadre while only 6 are in junior staff level cadre.

\subsection{Description of Research Variables}

The research variables are described using frequency, percentages, mean and standard deviation. In interpreting the mean score, it is assumed that values that are above 3 shows that majority of the respondents "agreed" with the statements while values that fall below 3 shows that majority of the respondents "disagreed" with the statements. The calculated values are scored as follows: below 1.45 is scored very low, $1.45-2.44$ is low, $2.45-3.44$ is moderate, 3.45 - 4.44 is high and 4.45 and above is very high (Social Economic Rights and Accountability Project [SERAP], 2018). The mean and standard deviation results are presented in Table 2 (See Appendix A for details). 
Table 2: Mean and standard deviation of research variables

\begin{tabular}{|c|l|c|c|c|}
\hline $\mathbf{S} / \mathbf{N}$ & Variables & Mean $(\overline{\mathbf{X}})$ & $\begin{array}{c}\text { Standard } \\
\text { Deviation }\end{array}$ & Comment \\
\hline 1 & Reward system & 3.769 & 0.7274 & High \\
\hline 2 & Supervisor-subordinate relationship & 4.057 & 0.5082 & High \\
\hline 3 & Opportunity for career development & 4.057 & 0.4865 & High \\
\hline 4 & Affective commitment & 3.673 & 0.6279 & High \\
\hline 5 & Continuance commitment & 3.815 & 0.5259 & High \\
\hline 6 & Normative commitment & 4.065 & 0.4246 & High \\
\hline
\end{tabular}

Table 2 shows the overall mean and standard deviation of the different variables as perceived by the respondents as follows: reward system $(\overline{\mathrm{X}}=3.769 ; \mathrm{SD}=0.7274)$; supervisor-subordinate relationship $(\overline{\mathrm{X}}=4.057 ; \mathrm{SD}=$ $0.5082)$; opportunity for career development $(\bar{X}=4.057 ; \mathrm{SD}=0.4865)$; affective commitment $(\overline{\mathrm{X}}=$ 3.673; $\mathrm{SD}=0.6279)$; continuance commitment $(\overline{\mathrm{X}}=3.815$; $\mathrm{SD}=0.5259)$; and normative commitment $(\overline{\mathrm{X}}=$ $4.065 ; \mathrm{SD}=0.4246)$. It can be concluded that respondents' perception of the variables examined namely: reward system, supervisor-subordinate relationship, opportunity for career development and commitment (affective, continuance and normative) in the Nigerian manufacturing sector using Guinness Nigeria Plc is high.

\subsection{Model Estimation and Interpretation}

This section contains the results of the estimated research model using regression analysis. Regression analysis was used to model the relationship between employee commitment and its determinants. The results are shown in Table 3 below:

Table 3: Estimated regression models of employee commitment

\begin{tabular}{|c|c|c|c|c|}
\hline Variables & $\begin{array}{r}\text { Affective } \\
\text { Commitment }\end{array}$ & $\begin{array}{l}\text { Continuance } \\
\text { Commitment }\end{array}$ & $\begin{array}{r}\text { Normative } \\
\text { Commitment }\end{array}$ & $\begin{array}{r}\text { Employee } \\
\text { Commitment }\end{array}$ \\
\hline \multirow{3}{*}{$\mathrm{C}$} & 0.1777 & 1.9804 & 1.7265 & 1.2949 \\
\hline & $(0.3439)$ & $(4.1754)$ & $(4.8616)$ & $(4.1189)$ \\
\hline & $\{0.7317\}$ & $\{0.0001\}$ & $\{0.000\}$ & $\{0.0001\}$ \\
\hline \multirow{3}{*}{ Reward System } & 0.2676 & 0.2818 & 0.0373 & 0.1956 \\
\hline & $(3.3423)$ & $(3.8339)$ & $(0.6772)$ & $(4.0142)$ \\
\hline & $\{0.0012\}$ & $\{0.0002\}$ & $\{0.5001\}$ & $\{0.0001\}$ \\
\hline \multirow{3}{*}{ Supervisor-Subordinate Relationship } & 0.2203 & -0.0858 & 0.3667 & 0.1671 \\
\hline & $(1.7323)$ & $(-0.7353)$ & $(4.1955)$ & $(2.1591)$ \\
\hline & $\{0.0869\}$ & $\{0.4642\}$ & $\{0.0001\}$ & $\{0.0337\}$ \\
\hline \multirow{3}{*}{ Opportunity for Career Development } & 0.3926 & 0.2763 & 0.1751 & 0.2814 \\
\hline & $(2.8970)$ & $(2.2207)$ & $(1.8801)$ & $(3.4119)$ \\
\hline & $\{0.0048\}$ & $\{0.0291\}$ & $\{0.0636\}$ & $\{0.0010\}$ \\
\hline R-Squared & 0.3772 & 0.2521 & 0.3568 & 0.4662 \\
\hline
\end{tabular}




\begin{tabular}{|l|r|r|r|r|}
\hline Variables & $\begin{array}{r}\text { Affective } \\
\text { Commitment }\end{array}$ & $\begin{array}{r}\text { Continuance } \\
\text { Commitment }\end{array}$ & $\begin{array}{r}\text { Normative } \\
\text { Commitment }\end{array}$ & $\begin{array}{r}\text { Employee } \\
\text { Commitment }\end{array}$ \\
\hline Adj. R-Squared & 0.3550 & 0.2254 & 0.3339 & 0.4472 \\
\hline F-statistic & 16.9598 & 9.4377 & 15.5338 & 24.4555 \\
\hline Prob (F-statistic) & 0.0000 & 0.0000 & 0.0000 & 0.0000 \\
\hline Observations & 88 & 88 & 88 & 88 \\
\hline Durbin-Watson Stat & 2.2062 & 2.2117 & 1.8214 & 1.9737 \\
\hline
\end{tabular}

Note: T-Stat \& P-Values are in bracket ( ) and parenthesis \{ \} respectively.

4.3.1 Affective Commitment: The results show that two of the three independent variables are significant at $5 \%$. Reward system and opportunity for career development have positive and statistically significant relationship with affective commitment. The R-Squared of 0.3772 shows that the explanatory variables account for $37.72 \%$ of the variations in the dependent variable. The F-statistic of 16.9598 is significant at $\mathrm{p}<0.05(\mathrm{p}=0.0000)$. This shows that there is a statistically significant relationship between the dependent and the independent variables. The Durbin-Watson statistic of 2.2062 reveals the absence of multi-collinearity.

4.3.2 Continuance Commitment: The results also show that two of the three independent variables are significant at 5\%. Reward system and opportunity for career development have positive and statistically significant relationship with continuance commitment. The R-Squared of 0.2521 shows that the explanatory variables account for $25.21 \%$ of the variations in the dependent variable. The F-statistic of 9.4377 is significant at $\mathrm{p}<0.05(\mathrm{p}=0.0000)$. This shows that there is a statistically significant relationship between the dependent and the independent variables. The Durbin-Watson statistic of 2.2117 reveals the absence of multi-collinearity.

4.3.3 Normative Commitment: The results show that only one out of the three independent variables is significant at 5\%. Supervisor-subordinate relationship positively and significantly impact normative commitment. The R-Squared of 0.3568 shows that the explanatory variables account for $35.68 \%$ of the variations in the dependent variable. The F-statistic of 15.5338 is significant at $p<0.05(p=0.0000)$. This shows that there is a statistically significant relationship between the dependent and the independent variables. The Durbin-Watson statistic of 1.8214 reveals the absence of multi-collinearity.

4.3.4 Employee Commitment: Table 3 shows that all the three independent variables are significant at 5\%. Reward system, supervisor-subordinate relationship and opportunity for career development positively and significantly impact employee commitment in Guinness Nigeria Plc. The R-Squared of 0.4662 shows that the explanatory variables account for $46.62 \%$ of the variations in the dependent variable. The F-statistic of 24.4555 is significant at $\mathrm{p}<0.05(\mathrm{p}=0.0000)$. This shows that there is a statistically significant relationship between the dependent and the independent variables. The Durbin-Watson statistic of 1.9737 reveals the absence of multicollinearity.

\section{Discussion of Findings}

Firstly, this study found that reward system positively and significantly impact employee commitment. This is supported by the findings of George and Jones (1996) that organization that are more committed to workers' welfare are more likely to gain more committed workforce. Rewards systems in form of good salary, timely payment of allowances and other fringe benefits will promote employee commitment to their jobs.

Secondly, supervisor-subordinate relationship positively and significantly related to employee commitment. Empirical findings reveal that employees' commitment to the organization is greatly influenced by the amount of opportunity available for employees to develop their chosen career (Mathieu \& Zajac, 1990), recognition in making decisions, as well as how the organization's feedback mechanisms are with respect to job performance and role (Porter, Steers, Mowday \& Boulian, 1974). Moreover, Benkhoff (1997) found that commitment among employees is directly and positively related to the position they occupy at a particular period of time.

Finally, this study found that opportunities for career development significantly influence employee commitment in the Nigerian manufacturing industry. This is in consonance with Masson et al. (2008) that found that training staff members helped them to manage, plan and cope with their work and also offered emotional support helped to improve overall self-efficacy and commitment to duties. This is supported by Karatepe (2011) who found that 
training programmes that centred on employees' task-related and behavioural skills improvement played a significant role in arousing a sense of obligation and commitment in workers to respond positively to their duties.

\section{Conclusion and Recommendations}

The focus of this study is the modelling of the determinants of employee commitment in the Nigerian manufacturing sector using Guinness Nigeria Plc as case study. The study ascertained the impact of reward systems, supervisor-subordinate relationship and opportunities for career development on employee commitment in the Nigerian manufacturing sector. The study concluded that employees of Guinness Nigeria Plc perceived reward systems, supervisor-subordinate relationship and opportunities for career development to be high and significantly influence employee commitment.

Based on the research findings and conclusion, the following recommendations were made for policy implications:

i. Guinness Nigeria Plc should sustain and improve on current strategy on reward system to enhance commitment among employees in the workplace.

ii. Cordial relationship between employees (subordinate) and supervisor should be sustained in the operations of organisations to promote trust and commitment in the workplace.

iii. Career development programmes in form of regular training, seminars and workshops should be organised by Guinness Nigeria Plc to sharpen the skills of the employees in carrying out their duties as well as preparing them for higher responsibilities in the future.

iv. Future studies should empirically explore the concept of employee commitment in as many manufacturing firms in Nigeria as possible to provide clearer perspectives on the subject matter.

\section{References}

Abdurrahim, E. (2012). Relationship among managerial support, job satisfaction and organizational commitment: A comparative study of nonprofit, for-profit and public sector in turkey. International Journal of Business, Humanities and Technology, 2(5), 179-190.

Abuga, S.M. (2010). Job satisfaction and employee commitment of fast food company x employees. A research paper submitted in partial fulfillment of the requirements for the Master of Science degree in training and development. The Graduate School, University of Wisconsin-Stout.

Akpan, C. P. (2013). Job security and job satisfaction as determinant of organizational commitment among university teachers in Cross Rivers state, Nigeria. British Journal of Education, 1(2), 82-93.

Albdour, A., \& Altarawneh, I. (2014). Employee engagement and organizational commitment: Evidence from Jordan. International Journal of Business, 19(2), 192-212.

Allen, A. J., \& Meyer, J. P. (1990). The measurement and antecedents of affective, continuance and normative commitment to the organization. Journal of Occupational Psychology, 63, 1-18.

Arnold, B. B. (2008). Work engagement: An emerging concept in occupational health psychology. Work and Stress, 22(3), 187-200.

Azeez, R. O., Jayeoba, F., \& Adeoye, A. O. (2016). Job satisfaction, turnover intention and organizational commitment. Journal of Management Research, 8(2), 102-114.

Bateman, T., \& Strasser. (1984). A longitudinal analysis of the antecedents of organizational commitment. Academy of Management Journal, 27, 95.

Benkhoff, B. (1997). Ignoring commitment is costly: New approaches establish the missing link between commitment and performance. Human Relations, 50(6), 701-726.

Burke, C. S., Sims, D. E., Lazzara, E. H., \& Salas, E. (2007). Trust in leadership: A multi-level review and integration. The Leadership Quarterly, 18, 606-632.

Cohen, A. (2003). Multiple commitments in the workplace: An integrative approach. Mahwah, NJ: Erlbaum.

Eric, S. (1994). The role of rewards on a journey to excellence. Management Decision, 32(5), 46.

Gangai, K. N., \& Agrawal, R. (2015). Job satisfaction and organizational commitment: Is it important for employee performance. International Journal of Management and Business Research, 5(4), 269-274.

George, J. M., \& Jones, G. R. (1996). Understanding and managing organizational behavior. California: Addison-Wesley Publishing Company, Inc. 
Goodale, J. C., Koerner, M., \& Roney, J. (1997). Analyzing the impact of service provider empowerment on perceptions of service quality inside an organization. Journal of Quality Managem lent, 2(2), 191-215.

Greenberg, J., \& Baron, R. A. (1997). Behavior in organizations: Understanding and managing the human side of work. Color Transparencies: Prentice Hall.

Hall, S.S.J. (1990). Quality assurance in the hospitality industry. Wisconsin: Quality Press.

Hanaysha, J., \& Tahir, P.R. (2015). Examining the effects of employee empowerment, teamwork, and employee training on job satisfaction. $3^{\text {rd }}$ Global Conference on Business and Social Science, 16-17 December, 2015, Kuala Lumpur, Malaysia.

Jahangir, N., Akbar, M. M., \& Haq, M. (2004). Organisational citizenship behaviour: Its nature and antecedents. BRAC University Journal, 1(2), 75-88.

Jason, A.C., Jeffery, A. L., \& Michael, J. W. (2011). Organizational behaviour (2 ${ }^{\text {nd }}$ edition). USA: McGraw Hill.

Karatepe, O. M. (2011). Procedural justice, work engagement, and job outcomes: Evidence from Nigeria. Journal of Hospitality Marketing and Management, 20(8), 855-878.

Kitson, M. (2003). Don't be fooled: These 4 terms are totally different!!! Available online from https://guardianinitiative.wordpress.com/2014/05/21/dont-be-fooled-these-4-terms-are-totally-different/.

Lapierre, L. M. (2007). Supervisor trustworthiness and subordinates' willingness to provide extra-role efforts. Journal of Applied Social Psychology, 37(2), 272-297.

Lawler, E. E. (1991). Paying the person: A better approach to management. Human Resource Management Review, 1, 145154.

Luthans, F. (1992). Organizational behaviour. McGraw-Hill: New York.

Malaolu, V. A., \& Ogbuabor, J. E. (2013). Training and manpower development, employee productivity and organizational performance in Nigeria: Empirical investigation. International Journal of Advances in Management and Economies, 2(5), 163-177.

Malhotra, N.K., Birks, D.F., \& Wills, P.A. (2013). Essentials of marketing research. Harlow: Pearson.

Masson, R. C., Royal, M. A., Agnew, T. G., \& Fine, S. (2008). Leveraging employee engagement: The practical implications. Industrial and Organisational Psychology, 23(1), 56-59.

Mathieu, J. E. \& Zajac, D. M. (1990). A review and meta-analysis of the antecedents, correlates, and consequences of organizational commitment. Psychological Bulletin, 108(2), 171-194.

Mayer, R. C., Davis, J. H., \& Schoorman, F. D. (1995). An integrative model of organisational trust. Academy of Management Review, 20, 709-734.

Meyer, J. P., Allen, N. J., \& Allen, N. J. (1997). Commitment in the workplace. Sage Publications.

Meyer, J.P., Becker, T.E., \& Van Dick, R. (2006). Social identities and commitments at work: Toward an integrative model. Journal of Organizational Behaviour,27, 665-683.

Miller, D., \& Lee, J. (2001). The people make the process: Commitment to employees, decision making and performance. Journal of Management, 27, 163-189.

Morrison, D., Cordery, J., Girardi, A., \& Payne, R. (2005). Job design, opportunities for skill utilization, and intrinsic job satisfaction. European Journal of Work and Organisational Psychology, 14, 59-79.

Mowday, R., Porter, L., \& Steers, R. (1982). Employee-organization linkages: The psychology of commitment, absenteeism, and turnover. New York: Academic Press.

Nartech, O. (2012). Reassessing the measurements of commitment in the workplace. Southern African Business Review, 18(7), 34-45.

Njoku, K. C., Ugwulebo, E. O., \& Iheriohanma, E. B. J. (2018). Fear of retirement and productivity in the Imo state public service, Nigeria. JORIND, 16(1). www.transcampus.org/journal; www.ajol.info/journals/jorind

Noe, R. A., Wilk, S. L., Mullen, E. J., \& Wanek, J. E. (2014). Employee development: Issues in construct definition and investigation of antecedents. Improving Training Effectiveness in WorkOrganizations, ed. JK Ford, SWJ Kozlowski, K. Kraiger, E. Salas, and MS Teachout (Mahwah, NJ: Lawrence Erlbaum, 1997), 153-189.

Porter, L. W., Steers, R. M., Mowday, R. T., \& Boulian, P. V. (1974). Organizational commitment, job satisfaction, and turnover among psychiatric technicians. Journal of applied psychology, 59(5), 603.

Singh, U., \& Srivastava, K. B. L. (2009). Interpersonal trust and organisational citizenship behavior. Psychological Studies, $54,65-76$ 
Vol.11, No.15, 2019

Sitkin, S. B., \& Roth, N. L. (1993). Explaining the limited effectiveness of legalistic "remedies" for trust/distrust. Organisational Science, 4, 367-392.

Social Economic Rights and Accountability Project (SERAP) (2018). Stealing the future: How Federal universities in Nigeria have been stripped apart by corruption. Lagos: SERAP

Truelove, S. (1992). Handbook of training and development. Oxford: Blackwell

Voydanoff, P. (1980). The implications of work-family relationships for productivity. Scarsdale, New York: Work in America Institute.

Williams, M. L., McDaniel, M. A., \& Nguyen, N. T. (2006). A meta-analysis of the antecedents and consequences of pay level satisfaction. Journal of Applied Psychology, 91(2), 392. 


\section{Appendix A}

\begin{tabular}{|c|c|c|c|c|c|c|}
\hline $\mathbf{S} / \mathbf{N}$ & Statement & SD & D & $\mathbf{U}$ & $\mathbf{A}$ & SA \\
\hline \multicolumn{7}{|c|}{ Reward System } \\
\hline 1 & I am satisfied with the salary I receive & $11(12.5 \%)$ & $53(60.3 \%)$ & $15(17.1 \%)$ & $7 \quad(8 \%)$ & $2 \quad(2.3 \%)$ \\
\hline 2 & I am paid my salary regularly & $17(19.4 \%)$ & $55(62.5 \%)$ & $10(11.4 \%)$ & $4 \quad(4.6 \%)$ & $2(2.3 \%)$ \\
\hline 3 & $\begin{array}{l}\text { Apart from salary, there are other staff welfare packages available } \\
\text { to entrench commitment }\end{array}$ & $19(21.6 \%)$ & $51(58 \%)$ & $8 \quad(9.1 \%)$ & $7 \quad(8 \%)$ & $3(3.5 \%)$ \\
\hline 4 & $\begin{array}{l}\text { The overall reward packages are reviewed and improved } \\
\text { occasionally. }\end{array}$ & $15(17.1 \%)$ & $43(48.9 \%)$ & $\begin{array}{c}12 \\
(13.7 \%)\end{array}$ & $\begin{array}{c}13 \\
(14.8 \%)\end{array}$ & $5 \quad(5.7 \%)$ \\
\hline \multicolumn{7}{|c|}{ Supervisor-Supervisor Relationship } \\
\hline 5 & My supervisor is very concerned with my welfare & $17(19.4 \%)$ & $51(58 \%)$ & $14(16 \%)$ & $6 \quad(6.9 \%)$ & $0 \quad(0 \%)$ \\
\hline 6 & My supervisor tries hard to be fair in dealing with others & $15(17.1 \%)$ & $57(64.8 \%)$ & $10(11.4 \%)$ & $6 \quad(6.9 \%)$ & $0 \quad(0 \%)$ \\
\hline 7 & $\begin{array}{l}\text { My supervisor is well qualified and experienced for the job he is } \\
\text { doing }\end{array}$ & $32(36.4 \%)$ & $45(51.2 \%)$ & $8 \quad(9.1 \%)$ & $2(2.3 \%)$ & $1 \quad(1.2 \%)$ \\
\hline 8 & I feel very confident about my supervisor's skills \& knowledge & $30(34.1 \%)$ & $50(56.9 \%)$ & $6 \quad(6.9 \%)$ & $1(1.2 \%)$ & $(1.2 \%)$ \\
\hline \multicolumn{7}{|c|}{ Opportunities for Career Development } \\
\hline 9 & $\begin{array}{l}\text { This organisation provides employees access to training } \\
\text { programmes }\end{array}$ & $30(34.1 \%)$ & $50(56.9 \%)$ & $7 \quad(8 \%)$ & $\begin{array}{c}1 \\
(1.2 \%)\end{array}$ & $\begin{array}{c}0 \\
(0 \%)\end{array}$ \\
\hline 10 & I have opportunity to learn new things while doing my job & $32(36.4 \%)$ & $48(54.6 \%)$ & $\begin{array}{c}7 \\
(8 \%)\end{array}$ & $1 \quad(1.2 \%)$ & $\begin{array}{c}0 \\
(0 \%)\end{array}$ \\
\hline 11 & $\begin{array}{l}\text { I am satisfied with the quality of orientation and training I } \\
\text { received for my current position }\end{array}$ & $21(23.9 \%)$ & $49(55.7 \%)$ & $\begin{array}{c}12 \\
(13.7 \%)\end{array}$ & $\begin{array}{c}5 \\
(5.7 \%)\end{array}$ & $(1.2 \%)$ \\
\hline 12 & $\begin{array}{l}\text { Training programmes organize by this company help me perform } \\
\text { my job better }\end{array}$ & $13(14.8 \%)$ & $52(59.1 \%)$ & $\begin{array}{c}15 \\
(17.1 \%)\end{array}$ & $\begin{array}{c}6 \\
(6.9 \%)\end{array}$ & $\begin{array}{l}2 \\
(2.3 \%)\end{array}$ \\
\hline \multicolumn{7}{|c|}{ Affective Commitment } \\
\hline 13 & I am proud to be part of my company & $11(12.5 \%)$ & $34(38.7 \%)$ & $17(19.4 \%)$ & $24(27.3 \%)$ & $\begin{array}{l}2 \\
(2.3 \%) \\
\end{array}$ \\
\hline 14 & I feel my values and those of my company are similar & $17(19.4 \%)$ & $50(56.9 \%)$ & $12(13.7 \%)$ & $\begin{array}{c}6 \\
(6.9 \%) \\
\end{array}$ & $\begin{array}{l}3 \\
(3.5 \%) \\
\end{array}$ \\
\hline 15 & I feel emotionally attached to this company & $18(20.5 \%)$ & $40(45.5 \%)$ & $17(19.4 \%)$ & $12(13.7 \%)$ & $\begin{array}{c}1 \\
(1.2 \%)\end{array}$ \\
\hline 16 & I feel a strong sense of belonging in this company & $17(19.4 \%)$ & $47(53.5 \%)$ & $18(20.5 \%)$ & $\begin{array}{c}6 \\
(6.9 \%) \\
\end{array}$ & $\begin{array}{c}0 \\
(0 \%) \\
\end{array}$ \\
\hline \multicolumn{7}{|c|}{ Continuance Commitment } \\
\hline 17 & Too much of my life would be disrupted if I leave this company & $9(10.3 \%)$ & $29(33 \%)$ & $12(13.7 \%)$ & $\begin{array}{c}26 \\
(29.6 \%)\end{array}$ & $\begin{array}{c}12 \\
(13.7 \%)\end{array}$ \\
\hline 18 & $\begin{array}{l}\text { Staying with my job in this company is a matter of necessity as } \\
\text { much as I desire. }\end{array}$ & $16(18.2 \%)$ & $59(67.1 \%)$ & $\begin{array}{c}8 \\
(9.1 \%)\end{array}$ & $\begin{array}{l}5 \\
(5.7 \%)\end{array}$ & $\begin{array}{c}0 \\
(0 \%)\end{array}$ \\
\hline 19 & I believe I have too few options to consider leaving this company & $27(30.7 \%)$ & $54(61.4 \%)$ & $\begin{array}{c}7 \\
(8 \%)\end{array}$ & $\begin{array}{c}0 \\
(0 \%)\end{array}$ & $\begin{array}{c}0 \\
(0 \%)\end{array}$ \\
\hline 20 & I feel the cost for leaving my company is too high & $25(28.5 \%)$ & $51(58 \%)$ & $\begin{array}{c}9 \\
(10.3 \%) \\
\end{array}$ & $\begin{array}{c}1 \\
(1.2 \%) \\
\end{array}$ & $\begin{array}{c}2 \\
(2.3 \%) \\
\end{array}$ \\
\hline \multicolumn{7}{|c|}{ Normative Commitment } \\
\hline 21 & I am obliged to remain with this company & $27(30.7 \%)$ & $54(61.4 \%)$ & $\begin{array}{c}6 \\
(6.9 \%) \\
\end{array}$ & $\begin{array}{c}1 \\
(1.2 \%) \\
\end{array}$ & $\begin{array}{c}0 \\
(0 \%) \\
\end{array}$ \\
\hline 22 & This company deserve my loyalty & $27(30.7 \%)$ & $55(62.5 \%)$ & $\begin{array}{c}6 \\
(6.9 \%) \\
\end{array}$ & $\begin{array}{c}0 \\
(0 \%) \\
\end{array}$ & $\begin{array}{c}0 \\
(0 \%) \\
\end{array}$ \\
\hline 23 & $\begin{array}{l}\text { I would not leave this company right now because of my sense of } \\
\text { obligation to it }\end{array}$ & $12(13.7 \%)$ & $70(79.6 \%)$ & $\begin{array}{c}6 \\
(6.9 \%)\end{array}$ & $\begin{array}{c}0 \\
(0 \%)\end{array}$ & $\begin{array}{c}0 \\
(0 \%)\end{array}$ \\
\hline 24 & I would feel guilty if I leave this company now & $31(35.3 \%)$ & $25(28.5 \%)$ & $\begin{array}{c}12 \\
(13.7 \%)\end{array}$ & $18(20.5 \%)$ & $\begin{array}{c}2 \\
(2.3 \%)\end{array}$ \\
\hline
\end{tabular}

\section{Author's Bio-data}

